\title{
Patenting Activity on Functional Foods: A Brazilian Scenario
}

\author{
Daniele Hilachuk ${ }^{1}$, Claudia Crisóstimo ${ }^{1}$, Alvaro José Argemiro da Silva ${ }^{2}$ Daniel de Paula ${ }^{3 *}$
}

\begin{abstract}
The segment of functional foods is a global trend with expressive growth in recent years. Investments in innovation play an essential role in maintaining the competitiveness of food companies in an increasingly fierce market. This study provides an overview of innovation over the years 2008 to 2020 in the functional foods segment in Brazil by using patenting activity as an indicator of innovation. A patent search was conducted in the National Institute of Intellectual Property (INPI) database to identify patent application records on the following functional foods: (i) gluten-free (ii) lactose-free/low-lactose (iii) probiotic (iv) prebiotic and, (v) enriched/fortified products. The main IPC codes retrieved refer to class A23L (33\%), A61K (17\%), and A23C (10\%), confirming the deposits' relationship with human nutrition. From 2015 on, resident applicants stood out, especially in 2017, with the highest number of deposits in the period. Most patent applications target probiotics (35.3\%), followed by fortified/ enriched products (25.3\%), gluten-free (14.3\%), lactose-free/low-lactose (13.3\%), and prebiotics (11.8\%). Brazilian higher education institutions (HEIs) figure among the top resident patent applicants. University-industry partnerships and research-oriented collaborative networks appear to be a feasible way to foster innovation in the food industry in the country. In summary, the patenting activity of functional foods in Brazil has awakened in recent years, showing trends and opportunities for innovation in the functional food segment.
\end{abstract}

Keywords: intellectual property; patent; innovation; food industry; functional food; Brazil

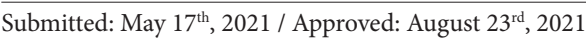

\section{Introduction}

Innovation can be considered the driving force behind a company's economic growth. From a historical viewpoint, the concepts of innovation have evolved in complexity, with many definitions and connotations - from the mid-1950s, when described linearly through conjugated processes, to more recent ones, such as diffuse and open innovation (Szymańska, 2017). The concept of open innovation emerged in the 2000s when Chesbrough (2003) observed that firms have started to search for innovation partners, despite intellectual property protection.

From the economic perspective, innovation arises as a disruption in the market, moving it out of balance, changing production patterns, and creating new ways of producing goods or services or entirely new industries, known as "creative destruction" (Schumpeter, 1988). A more recent evaluation of innovation theories points to four dimensions of innovation that can guide measurement: knowledge, novelty, implementation, and value creation (OECD \& Eurostat, 2018).

Decades ago, the food industry was recognized as a low researchintensity field and quite conservative in innovations introduced in the market (Bigliardi \& Galati, 2013). The food industry was mainly aimed at reformulating products to address changes in legislation. Conversely, today's consumers indicate to producers their preferences in a "chain inversion" process. According to this trend, innovations in the food industry are implemented in various ways, e.g., improving product quality and increasing variety, developing flexible processes and, providing better services (Bigliardi et al., 2020; Boland, 2008).
The demand for healthier food is one example that drives the food industry to innovate. An increasing number of consumers are becoming aware of functional foods with the hope of reaping additional health benefits, which may reduce certain disease risks or promote well-being, as indicated in the reports Euromonitor (Mascaraque, 2019) and Mintel's 2030 Global Food and Drink Trends (Zegler et al., 2019). According to Nielsen's Global Health \& Wellness Survey (2015), consumers in emerging countries are willing to pay more for products with healthy attributes. This is the opinion of more than $90 \%$ of respondents from Latin America, Asia-Pacific, Africa, and the Middle East. In developed markets, the percentage is lower, but still significant in Europe (79\%) and North America (80\%). According to the Brazil Food Trends report (2020), healthiness and wellness are also a trend in the food sector in the country, revealing that Brazilians value the consumption of foods with potential health benefits.

Intellectual property has largely been deemed a driver of innovation. The patent application, apart from being a mechanism to protect the invention, is a crucial indicator to measure innovation (Chang, Wu \& Leu, 2012; Kim \& Bae, 2016). By monitoring patenting activity, and especially the details of a patent application, it is possible to forecast upcoming market trends (Sharma \& Tripathi, 2017). Additionally, among the different indicators that can be used to assess the contribution of universities to the economic development of their country, patents have been of particular interest to management scholars. The economic impact can be determined with some ease due to the existence of a market for patented inventions, and the wide availability of reliable and comprehensive data sources increases the attractiveness of using patent-related indicators (Baldini, 2008).

(1) Technology Innovation Agency, Midwestern Parana State University - UNICENTRO, Guarapuava, Brazil

(2) Department of Business Administration, Midwestern Parana State University - UNICENTRO, Guarapuava, Brazil

(3) Department of Pharmacy, Midwestern Parana State University - UNICENTRO, Guarapuava, Brazil

*Corresponding author: ddepaula@unicentro.br 
In Brazil, the changes in national legislation in the last decades aimed to create a cooperative environment for research, development, and innovation in universities, public institutes, and companies (Brazil, 2016). Although advances have been made, Brazil still lacks technological innovation, as pointed out by Brazil's 24th position in the patent filing ranking compiled by the World Intellectual Property Organization (WIPO) (2020a). In the General Innovation Index, Brazil ranked 62 nd out of 131 countries (Cornell University, Insead, \& WIPO, 2020).

Despite the recent growth of the food sector in Brazil, we have not identified prospective studies on the patenting activity of functional foods in the last few years. Thus, this study aimed to outline a panorama of innovation on functional foods in Brazil. Based on patenting activity, we aim to highlight the main food categories, technological sectors, players and thus, provide data to support the research and development of innovative functional foods.

\section{Theoretical background}

This section brings concepts and regulations on intellectual property and functional foods that will help to understand how we structured the patenting activity in this sector.

\subsection{Intelectual Property}

According to the WIPO convention, intellectual property (IP) refers to creations of the mind, such as inventions, literary and artistic works, designs and symbols, and names and images used in commerce. An invention can be defined as a product or process that offers a new way of doing something or a new technical solution to a problem. A patent is an exclusive right granted for an invention by disclosing technical information to the public in a patent application. Thus, a patent is an IP protected in law, enabling people to earn recognition or financial benefit from what they invent or create. By striking the right balance between the interests of innovators and the broader public interest, the IP system aims to foster an environment in which creativity and innovation can flourish (WIPO, 2020b).

The industrial property takes a range of forms, including patents for inventions, industrial designs - aesthetic creations related to the appearance of industrial products, trademarks, service marks, layoutdesigns of integrated circuits, commercial names and designations, geographical indications, and protection against unfair competition (WIPO, 2020b). A patent for invention contains vast information on industrial property, including specialized areas, inventors, assignees and applicants, and geographical location. Patenting activity is an essential indicator of scientific, technological, and innovation development, supporting policy formulation and decision making in countries, funding agencies, universities, and companies (Clarke, 2018).

National industrial property offices are responsible for keeping custody of and providing information on patent applications filed in the country. Depending on the region of interest in protecting the invention, the patent application must be filed in each country's office, such as the United States Patent and Trademark Office (USPTO), the Japan Patent Office (JPO), the State Intellectual Property Office of the People's Republic of China (SIPO), and the European patent office (EPO). In Brazil, patent applications are managed by the National Institute of Industrial Property (INPI).

Created in 1970, the INPI is a federal agency responsible for improving, disseminating, and managing the Brazilian system of granting and protecting IP rights for the industry. Among INPI's services are the registration of trademarks, industrial designs, geographical indications, computer programs, and circuit topographies, the granting of patents, and the recording of franchise agreements and distinct forms of technology transfer (INPI, 2021).

Aside from holding valuable content, patent databases have the information arranged to allow for rapid search and retrieval of data. Patentometric analysis can serve several purposes, including (i) searching for trends through the state of the art, technology history, and new topics for academic research; (ii) visualizing the most recent inventions, verifying the originality of proposals and scientific research papers; (iii) identifying the level of exploitation of the technology; (iv) searching for potential stakeholders in the acquisition of the technology to be exploited; and (v) searching for technical alternatives for problem-solving (Clarke, 2018).

The International Patent Classification (IPC) and the Cooperative Patent Classification (CPC) constitute the current categorization systems. According to these classifications, each patent application receives a code composed of letters and numbers, allowing it to identify the patent application group. The IPC and the CPC exhibit similarities, as both are organized into groups and subdivided into classes and subclasses (WIPO, 2020b).

More than 90 countries adopt the IPC, becoming the most widely used classification to date. The IPC has a close correlation with the quality of technical information as it provides several essential data to support analyses, including the elaboration of patent indicators (WIPO, 2020b). In turn, the CPC covers more details and has been gradually gaining popularity, as it yields more accurate results than IPC. In Brazil, since 2014, the INPI has been registering new patent documents in the CPC system (INPI, 2021).

\subsection{Functional foods}

The concept of functional foods was first introduced in Japan in 1984 via large-scale systematic research into the emerging function of foods. Sponsored by Japan's Ministry of Education, Science, and Culture, the goal of this research was to create a regulatory system to approve certain foods with health benefit claims and thus help the population choose healthier products and consequently decrease the government's high healthcare costs (Arai, 1996). An ad hoc group engaged in the discussion about the history of food research in Japan proposed the concept and terminology of "functional food," with the revival of an ancient Chinese proverb that said "medicine and food are isogenic" (Abe, 2015). 
From the product viewpoint, functional foods can be defined as (Bigliardi \& Galati, 2013; Kotilainen et al., 2006; Spence, 2006):

- Fortified products: foods having an increased level of their existing nutrients, i.e., eggs with increased omega-3 content;

- Enriched products: foods containing new nutrients or components not typically found in a particular food, i.e., margarine fortified with plant sterols;

- Altered products: foods having a harmful component removed or replaced by a healthy component, i.e., chewing gum sweetened with xylitol instead of sugar;

- Enhanced commodities: changes in the raw commodities that have altered nutrient composition, i.e., fermentation with specific bacteria to yield bioactive peptides.

Functional foods can also be classified in an alternative way, according to their purpose (Bigliardi \& Galati, 2013; Makinen-Aakula, 2006):

- Foods that contribute to life or improve the lives of children, like prebiotics and probiotics;

- Foods that reduce an existing health risk problem, such as high cholesterol or high blood pressure;

- Foods that make life easier, such as lactose-free or gluten-free products.

Despite several definitions, in most countries, no legislative regulation exists for the term functional foods. Thus, establishing a limit between conventional and functional foods is challenging even for nutritionists and experts on the subject. The European legislation, for example, considers functional foods not as a specific food category but as a concept (Coppens, Da Silva \& Pettman, 2006).

In Brazil, functional foods are regulated by the National Health Surveillance Agency (ANVISA). Since 2018, foods with functional or health properties are placed under the category of food supplements. Vitamin and mineral supplements, bioactive substances and probiotics, supplements for athletes, food supplements for pregnant and lactating women are types of functional foods designated as food supplements (Brazil, 2018). The food supplement category arose to regulate the manufacturing and commercialization of functional foods and foster innovation in this sector. Thus, the public gets safer, and higher quality food products since improvements have been proposed in quality control and risk management for consumption.

\section{Method}

\subsection{Search strategy and data collection}

A patent search was conducted on the INPI database to identify patent application records for functional foods in Brazil. The INPI database (https://busca.INPI.gov.br/pePI/) is a free-of-charge tool for patent search that retrieves information from documents on applicants, inventors, legal status (e.g., granted, expired, under examination), and IPC classification system, according to the terms established in the industrial property legislation (INPI, 2021). The patent search was conducted in January 2021, and the search period was delimited from 2008 to 2020, as any shorter period would not result in an adequate sample due to patent application and publication procedures. A more extended period would include obsolete inventions.

The search was performed in the "title" and "abstract" fields with keywords in the native language Portuguese. When applicable, the truncation symbol asterisk $\left(^{*}\right)$ was used at the end of the keywords to broaden the search to terms beyond the word's root. The keywords used in the search were "gluten"; "lactose"; "probiotic*"; "prebiotic"; "enriquecid*", which means "enriched ${ }^{*}$ "; fortificad ${ }^{*}$, which means "fortified ${ }^{* ”}$. In this first stage, the search retrieved 1,865 patent application records. We selected only deposits containing IPCs listed in section "A" or "C" in a previous analysis.

\subsection{Data analysis}

The patent applications retrieved in the search were characterized as follows: (i) food type: gluten-free, lactose-free or low-lactose, probiotic, prebiotic, enriched/fortified; (ii) food sector: product, process, biotechnology, and preservation; (iii) status: retired, lapsed, granted, revoked, dead and pending; (iv) ownership: individual, legal entity, higher education institution (HEI), research institute; (v) applicant's origin: resident and non-resident; (vi) geographic region - for resident applicants, and (vii) IPC section, classes, and subclasses.

Using the summative content analysis technique (Hsieh \& Shannon, 2005), the keywords and text content were analyzed to understand their contextual usage and to verify whether the records corresponded to functional food patents according to the established categories for food types (gluten-free, lactose-free/low-lactose, probiotic, prebiotic, enriched/fortified) and food sectors (product, process, biotechnology, and preservation). The applications retrieved by the terms "gluten" and "lactose" were analyzed and further classified as patents dealing with gluten-free and lactose-free or low-lactose products. The documents retrieved by the terms "enriquecid*" and "fortificad*" were grouped in the same category, "enriched/fortified food." After the manual screening, e.g., removal of duplicate documents, 608 records remained, which form the core of this study (Table 1).

Descriptive statistical analyses were used to characterize the documents retrieved using descriptive measures, frequency distribution, and data correlation. Using Gephi software, two collaborative networking metrics, node size, and edge weight, were adopted to analyze the partnerships among the applicants and the respective number of co-authored patent applications. 
Table 1: Search strategy and summary of records retrieved in the patent search - INPI database, 2008-2020.

\begin{tabular}{|c|c|c|c|c|c|}
\hline \multicolumn{2}{|c|}{$\begin{array}{l}\text { 1st Step } \\
\text { Patent searching }\end{array}$} & \multirow{2}{*}{$\begin{array}{l}\text { 2nd Step } \\
\text { Filtering by IPCs' } \\
\text { sections A and C }\end{array}$} & \multicolumn{2}{|c|}{$\begin{array}{c}\text { 3th Step } \\
\text { Document selection and categorization after content } \\
\text { analysis }\end{array}$} & \multirow{2}{*}{$\begin{array}{c}\text { 4rd Step } \\
\text { Removal of duplicated } \\
\text { documents }\end{array}$} \\
\hline Keywords & Title / Abstract & & Categories & Retrieved records & \\
\hline Gluten & 217 & \multirow{6}{*}{-100} & Gluten-free & 103 & \multirow{6}{*}{-114} \\
\hline Lactose & 253 & & Lactose-free or Low-lactose & 97 & \\
\hline Prebiotic $^{*}$ & 136 & & Prebiotic & 84 & \\
\hline Probiotic $^{*}$ & 518 & & Probiotic & 254 & \\
\hline Enriched* / Enriquecid ${ }^{*}$ & 699 & & Enriched/ & \multirow{2}{*}{184} & \\
\hline Fortified $^{*} /$ Fortificad $^{*}$ & 42 & & Fortified & & \\
\hline Total & 1,865 & 1,765 & & 722 & 608 \\
\hline
\end{tabular}

\section{Results and Discussion}

\subsection{Patenting activity on functional foods in Brazil: Annual evolu-} tion and IPC classification

The patenting activity on functional foods in Brazil over the years 2008 to 2020 and the classification by IPC sections, classes, and subclasses are shown in Figure 1. Up to 2012, non-resident patent applications prevailed. From 2015 on, resident deposits have stood out, especially in 2017, with the highest number of records in the period. The 18-month confidentiality period causes an apparent reduction in the number of patent applications in 2019 and 2020. The new technologies are usually deposited in countries with potential for manufacturing and commercialization of the innovation. Although the annual evolution shows a growing trend in the number of resident applications in recent years, the amount of non-resident deposits is still significant, indicating Brazil is a target market for multinational companies.

The search retrieved 626 distinct IPC codes. Since most of the patents admit more than one IPC section, class, or subclass, the number of records totaled 2,057 codes. Most of the retrieved codes (87\%) refer to section "A," which represents "Human Necessities." In this section, class A23L (foods or foodstuffs; their treatment, not covered by other classes) correspond to 33\%, followed by A61K (preparations for medical, dental, or toilet purposes) with $17 \%$ and $\mathrm{A} 23 \mathrm{C}$ (dairy products, e.g. milk, butter, cheese; milk or cheese substitutes; making thereof) with $10 \%$ of the patent applications. These data confirm the relationship of the deposits with human nutrition. Section " $C$ ", referring to "Chemistry; Metallurgy", represents $12 \%$ of the total deposits and includes technologies related to microorganisms and fermentation processes, more specifically in class and section C12N (microorganisms or enzymes; compositions thereof; propagating, preserving, or maintaining microorganisms; mutation or genetic engineering; culture media) and $\mathrm{C} 12 \mathrm{P}$ (fermentation or enzyme-using processes to synthesize a desired chemical compound or composition or to separate optical isomers from a racemic mixture).
Figure 1. Patenting activity on functional foods in Brazil: Annual evolution (A) and classification by the IPC (B). Patents are assigned into one or more sections, classes, or subclasses of the IPC.

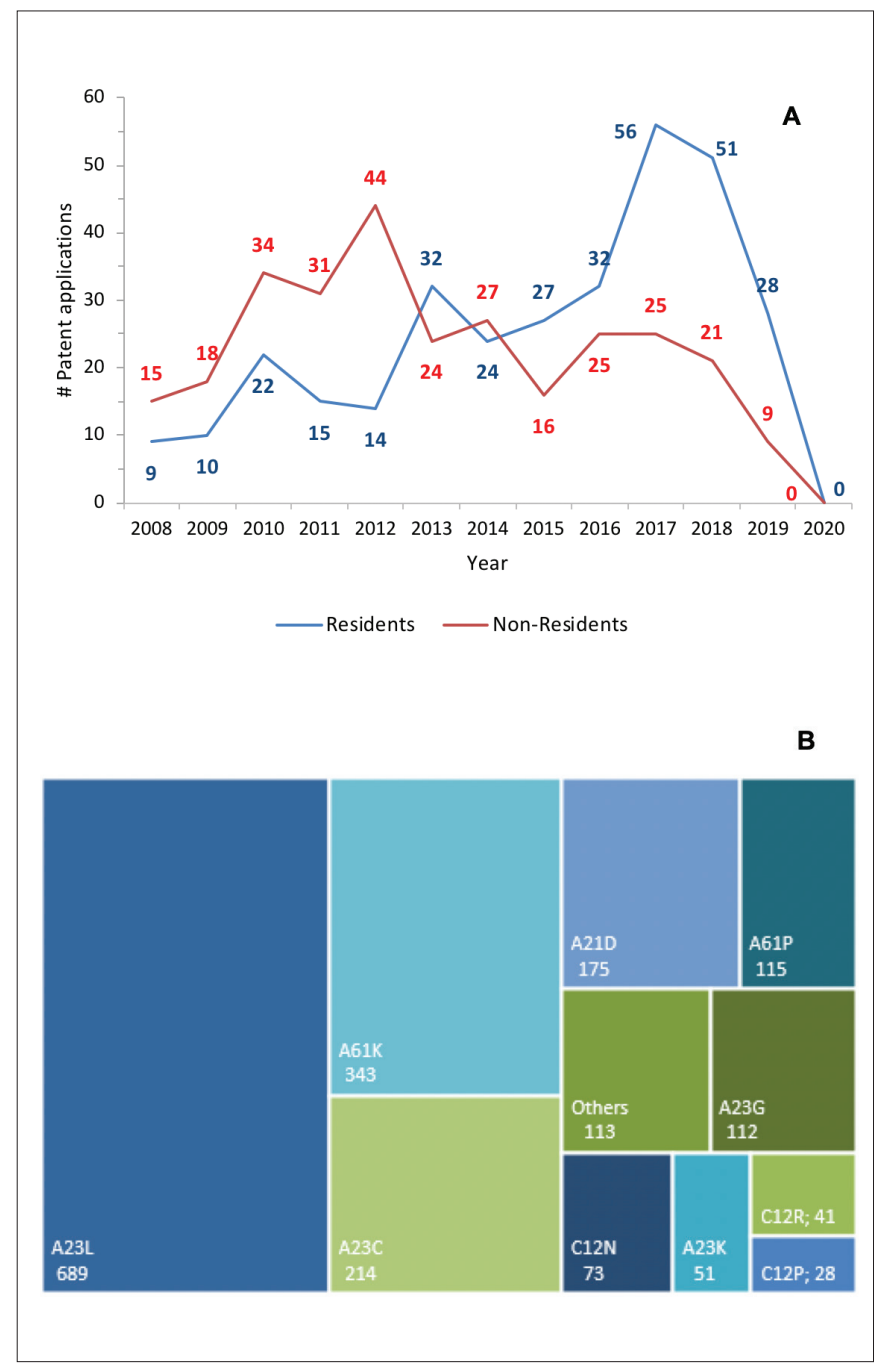


4.2 Distribution of functional food patent applications per applicants' origin and Brazilian geographic regions

The origin of the patent applicants is illustrated in Figure 2. Brazil stands out in comparison to the other countries with 320 requests, followed by the European Union (90), the United States (83), Switzerland (69), and the Netherlands (20). Apart from the domestic applicants, the countries with the highest number of deposits are notoriously advanced economies and recognized for their investments in innovation. Long-term investments in innovation will reflect in shorter and leaner technology cycles, translating into a more efficient transformation of the invention into a product. As an example, we can cite the 2020 Global Innovation Index ranking with Switzerland in the first place, the United States in third, and the Netherlands in fifth (Cornell University, Insead, \& WIPO, 2020).

Brazil's continental distribution demands an analysis based on geographical sub-regions to understand the country's socio-economic differences more clearly. In Figure 2B, we can observe that the Northeast region stands out with $35 \%$ of the patent applications, followed by the Southeast (31\%), South (24\%), and lastly, the Midwest (7\%) and North (3\%) regions. According to the Brazilian Innovation Index (FIEC, 2020), the states in the southern and southeastern regions perform better in innovation and economic development, while the states in the north stand in a disadvantageous position.

Figure 2. Distribution of functional food patent applications in Brazil (2008-2020) per applicants' origin (A) and Brazilian geographic regions (B).

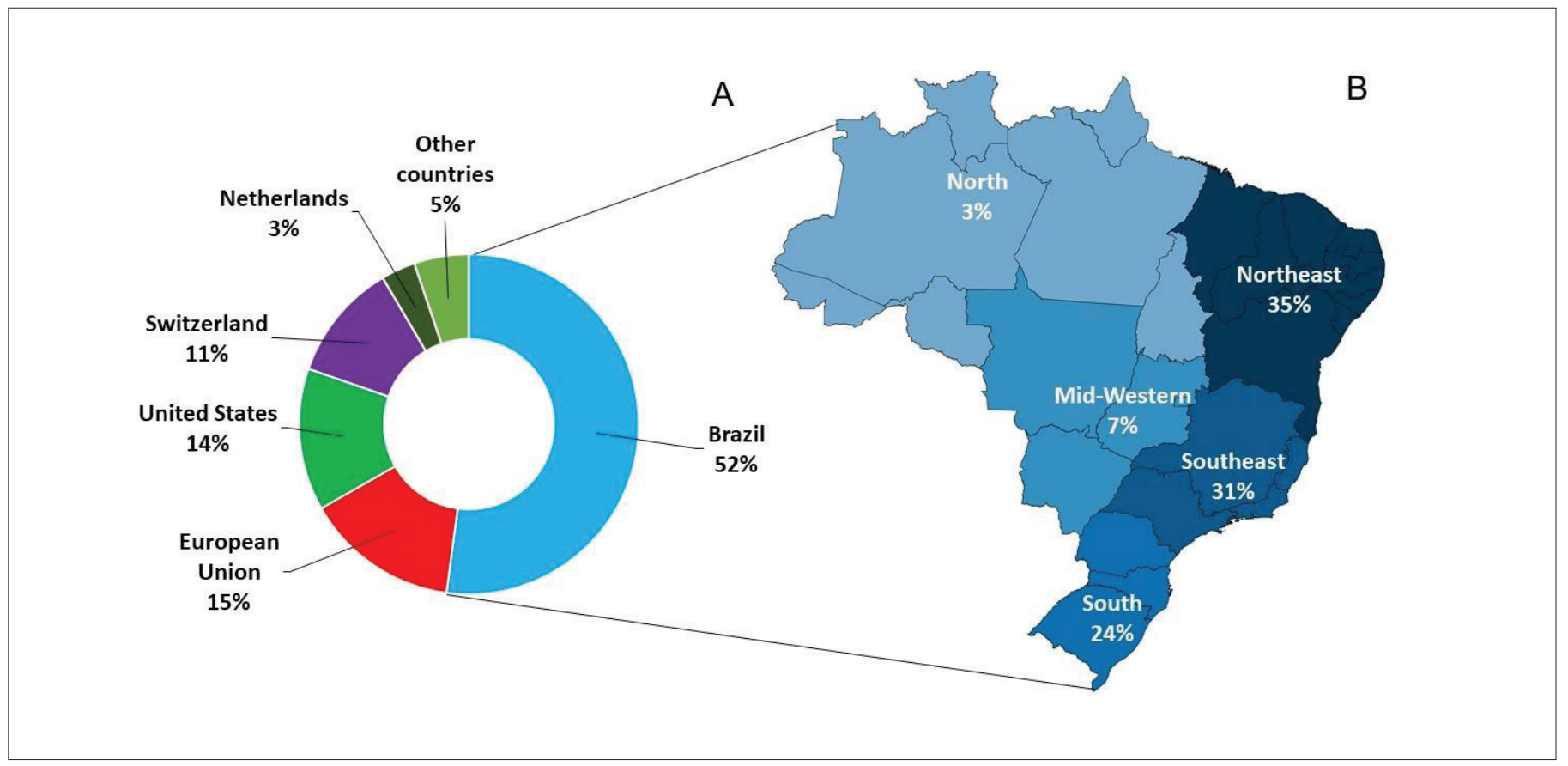

\subsection{Patent classification by food type and sector}

The classification of patent applications by food type and sector is shown in Figure 3. Most patent applications are probiotics (35.3\%), followed by fortified/enriched (25.3\%), gluten-free (14.3\%), lactosefree/low-lactose (13.3\%), and prebiotics (11.8\%) products. Apart from probiotics, resident applicants lead the ranking of deposits in each food type (Figure 3A). The gluten- and lactose-free products belong to the current "free-from" movement, strongly related to the growing perception of healthier and more natural products. The health-conscious consumer and fashionable eating habits towards gluten- and dairy-free options are likely to keep contributing to the bright future of the free-from movement (Mascaraque, 2019). Besides, the offering of fortified/enriched foods to address malnutrition is particularly relevant in economically developing nations, including Brazil, and it is estimated to bring further growth over the coming years. 
Figure 3. Patenting activity on functional foods in Brazil (2008-2020): Classification by food type (A) and food sector (B). Patents are assigned into one or more categories.
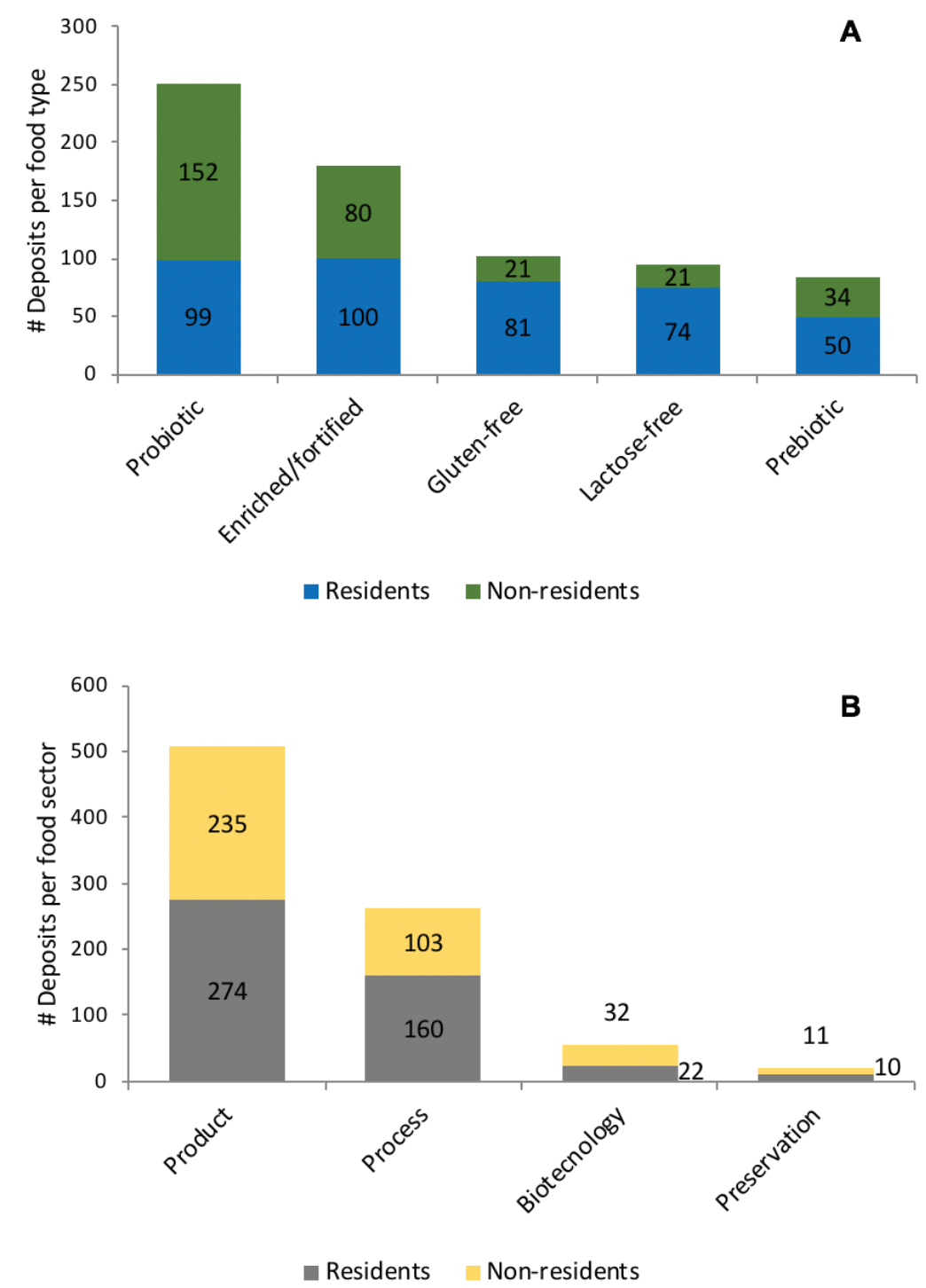

Patent applications were categorized under the following food sectors: Products (60.1\%), Processes (31.1\%), Biotechnology (6.4\%), and Preservation $(2.4 \%)$ as shown in Figure 3B. Launching products periodically on the market is an essential requirement for food companies to stay competitive. Offering innovative products implies, therefore, modifications in the manufacturing process or adopting new processing technologies. Additionally, innovations in the preservation field are emerging to meet consumer demands for high-quality food, minimally processed, microbiologically safe, and above all, bearing an extended shelf life (Clodoveo et al., 2016).

Biotechnology is an interdisciplinary science found at various stages of the food supply chain - from genetically modified seeds for planting to the industry that further relies on fermentation processes to deliver highly nutritional products (Rai, Pandey \& Sahoo, 2019; Vanholme et al., 2013). The inexpressive records of patent applications in the biotechnology sector could indicate that multinational companies are more interested in maintaining in Brazil only manufacturing and commercialization processes, keeping the R\&D department confined to their country of origin.

Some inventions deserve to be highlighted, such as the production of active yeast enriched with iron. The innovation lies in incorporating iron ions by the yeast without harming its fermentative ability, which can be used in baking processes. The yeast obtained can be employed in the development of nutraceutical products for anemia prevention and food supplementation and can even be used in the composition of school meals and animal feed (Gaensly, Brand \& Bonfim, 2012). 
A differentiated form of beer production with functional properties arises as another invention (Oliveira et al., 2016). It is an acid beer supplemented with lactic bacteria isolated from the semi-arid region of Bahia, Lactobacillus plantarum, which helps in the biotech-brewing process by commercial yeast Saccharomyces cerevisiae using grapes as an additive to the brewing malt.

The development of fruit pulp microcapsules for beverages also deserves attention (Pagani et al., 2014). This invention refers to the ionic gelation process with hydrocolloid solutions to produce fruit pulp microcapsules used to fortify beverages intended for human consumption, preferably mineral water. This product aims to add value to fruit pulps, which are sources of nutritional constituents and are commonly consumed in the form of juices, and encourage the population, especially children, to consume the recommended daily amount.

4.4 The legal status of functional food patent applications in Brazil The patent provisions and the drafting and prosecution of patent applications are complex and time-consuming until the patent letter is granted. Figure 4 shows the legal status of functional food patent applications at the INPI office for 2008-2020. Most of the deposits (52.8\%) are in the examination stage, which means a considerable backlog of patent applications waiting for a patent letter to be granted.

Figure 4. The legal status of functional food patent applications in Brazil (2008-2020).

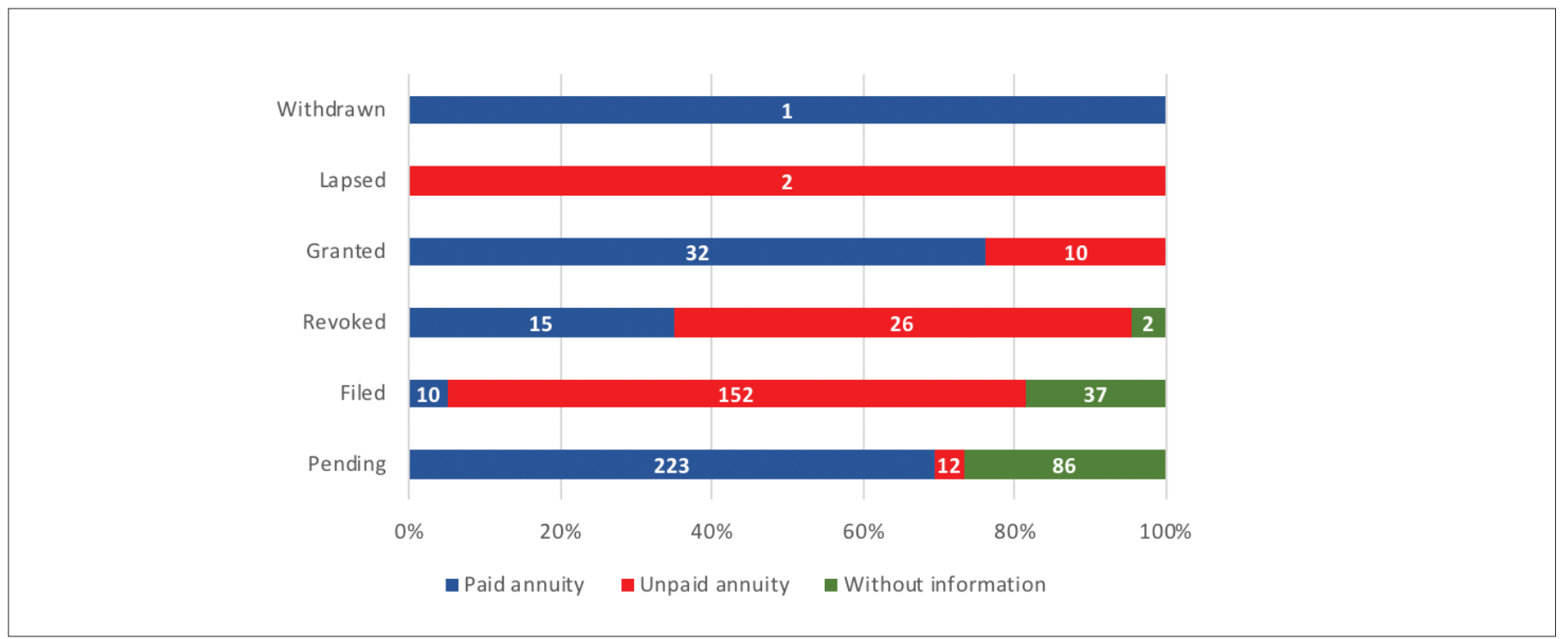

The so-called patent backlog of patent offices consists of all applications that have not been examined or those that exceed the work capacity of the office (Mitra-Kahn et al., 2013). The backlog reduces the effectiveness of the patent system by causing an environment of uncertainty and legal insecurity, compromising the effectiveness of the patent institution and the promotion of the country's economic and technological development (Garcez Júnior \& Moreira, 2017). In 2018 the INPI office implemented an action plan to reduce the patent examination backlog by $80 \%$ by the end of 2021 . Before that, the average waiting time was eight years. With the implementation of the plan, the time frame dropped to six years. In the coming years, the INPI office estimates that it will take less than 24 months to examine new applications (Ministry of Development, Industry and Foreign Trade, 2020).

The status of the remaining deposits is as follows: $32.7 \%$ dead, $7.1 \%$ rejected, and only $6.9 \%$ granted. The INPI office requires periodic payment of maintenance fees to maintain the validity of a patent after its issuance and during its term. Regarding dead applications (32.7\%), it was found that the main reasons for filing were the failure to fulfill the legal requirements for patentability and the non-payment of the annual fees for the maintenance of the applications.

\subsection{Top applicants of functional food patents in Brazil}

The principal applicants for functional food patents in Brazil are displayed in Figure 5. Brazilian higher educational institutions (HEIs) were grouped into a single category and represent the main resident patent applicants. In second and fourth positions, respectively, are Nestec and Société des Produits Nestlé, both companies owned by the multinational Swiss corporation Nestlé S.A., with worldwide recognition for operating in the food segment for more than a century. Apart from Brazil, where it has been operating since 1921, Nestlé is also active in more than 82 countries. Among all the Nestlé deposits in Brazil, $72 \%$ are in the probiotics food area. 
Figure 5. Top applicants on functional food patents in Brazil (2008-2020).

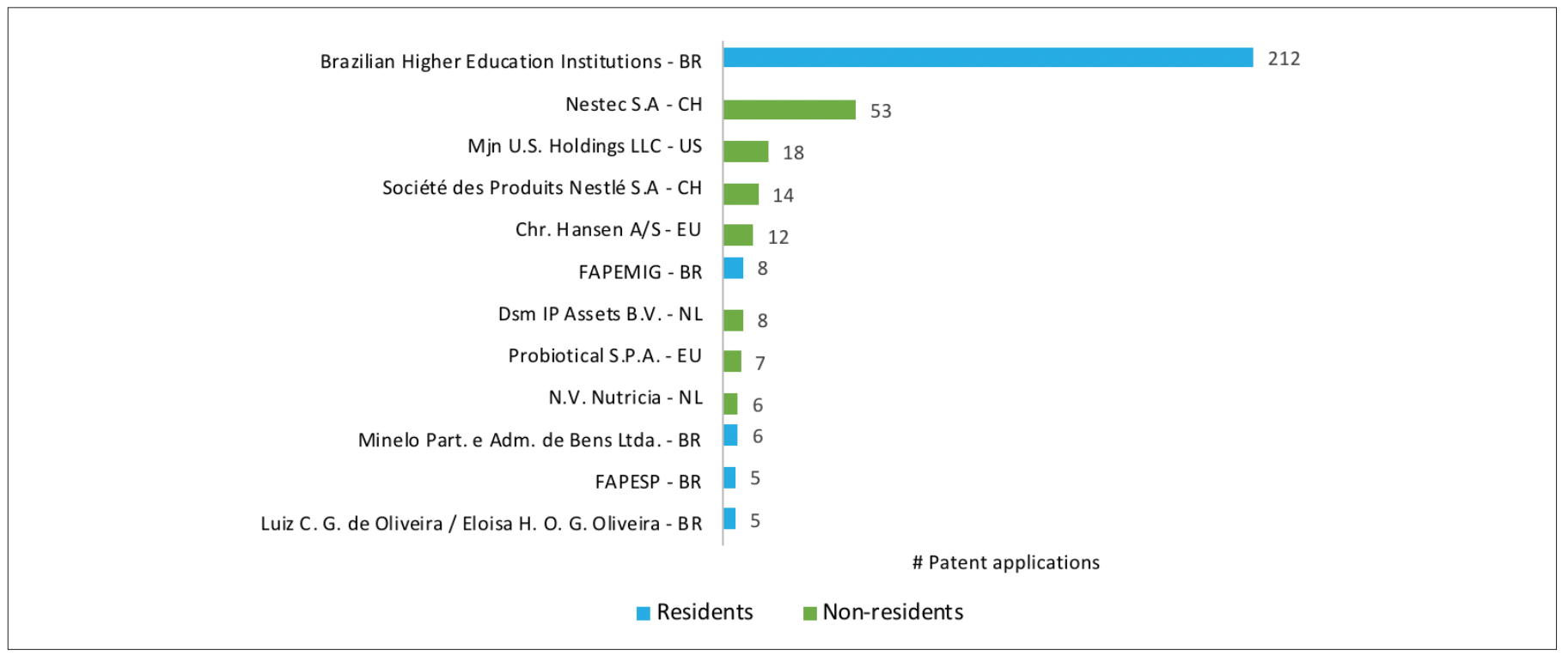

The century-old American multinational Mead Johnson Nutrition, recognized as a leader in developing products for infant nutrition, ranks among the top three applicants. In fifth place comes the Danish bioscience multinational CHR Hansen, considered a reference in developing natural solutions for the food, nutrition, pharmaceutical, and agricultural industries.

At the domestic level, the Public Foundations for Research Support (FAPs) stand out as entities that integrate the National System of Science and Technology in Brazil. FAPs operate across all Brazilian states, except for the state of Roraima, in the northern region (Alves, 2018). Two FAPs from the southeastern region feature in the top ranking: the Foundation for Research Support of the State of Minas Gerais (FAPEMIG) and the Foundation for Research Support of the State of São Paulo (FAPESP), the latter considered one of the leading agencies for fostering scientific and technological research in Brazil.

Noteworthy entrepreneurs include Mr. Luiz Carmine Giunti de Oliveira and Mrs. Eloisa Helena Orlandi Giunti Oliveira, owners of the company CarobHouse, who rank among the top applicants' natural persons. Their company is a pioneer in Brazil in the manufacture of carob-based products targeting healthy foods. The couple is also partner-owner of the company Minelo Participações Ltda, listed as significant applicants.
4.6 A collaborative network of Brazilian Higher Education Institutions (HEIs) based on functional food patenting activity

In the collaborative network displayed in Figure 6, it is possible to visualize the partnerships (edges) and the respective quantities (nodes) of patent applications on functional food held by Brazilian HEIs. The University of Campina Grande (UFCG) has the most significant number of applications totaling 22, followed by the Federal University of Recôncavo da Bahia (UFRB), and the Federal University of Paraíba (UFPB), both with 17 applications, and the University of São Paulo (USP) with 11.

The partnerships among HEIs and FAPs yielded the highest number of collaborative deposits, particularly UFLA-FAPEMIG and USP-FAPESP. The geographical location fostered cooperation, as UNICAMP in the southeast region has issued patents in partnership with HEIs located in other geographic regions. Only three companies developed innovations in partnership with Brazilian HEIs: BRF-USP, Ypi Indústria e Distribuição de Sorvetes-UFSC, and Agrosabor Indústria LtdaIFES. The collaborative networks took place almost exclusively at the domestic level, except for UTFPR's partnership with the Polytechnic Institute of Bragança (IPB) of Portugal. 
Figure 6. A collaborative network of Brazilian Higher Education Institutions (HEIs) based on functional food patenting activity (2008-2020).

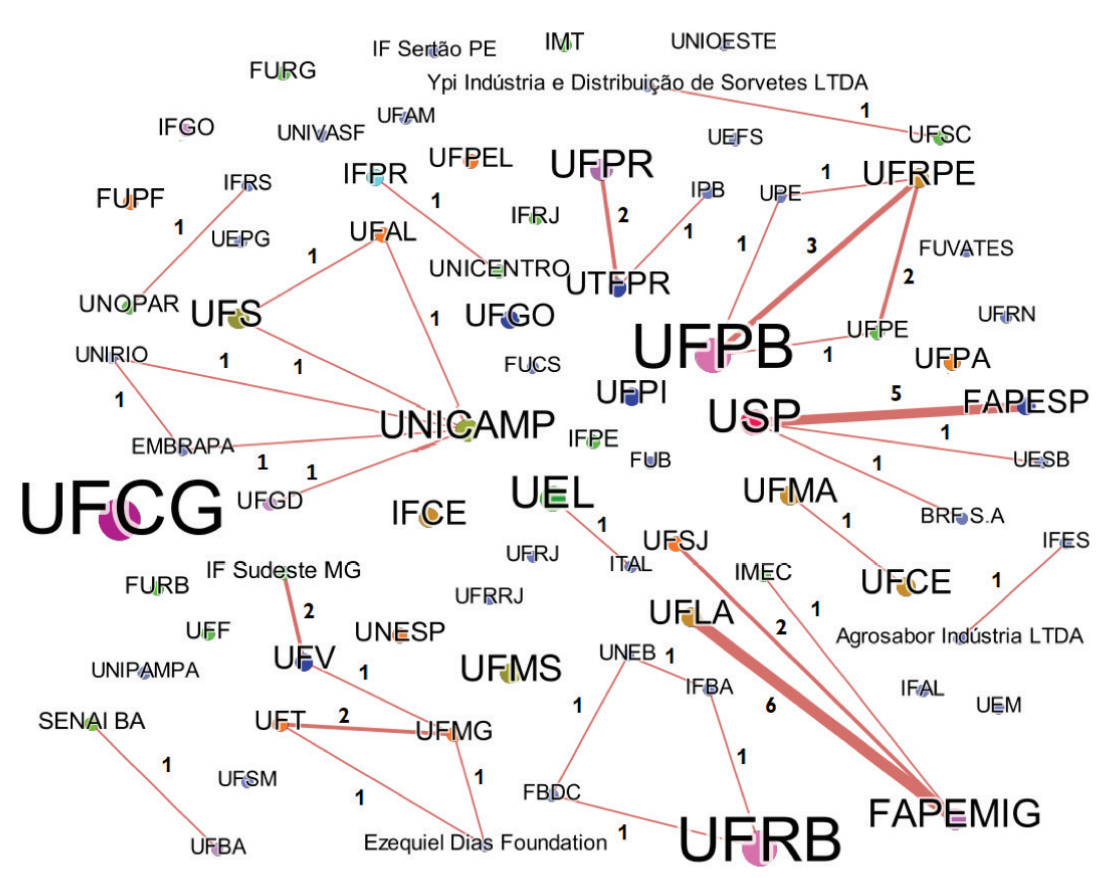

\# patent applications

\begin{tabular}{|c|c|c|}
\hline 22 & 10 & 6 \\
\hline 17 & 8 & 5 \\
\hline 11 & 7 & 4 \\
\hline
\end{tabular}

Brazilian HEIs represent $66.35 \%$ of total deposits on functional foods in Brazil. Scientists from universities are becoming more proactive in their efforts to commercialize research results. In recent years, there has been a growing view that universities could play a more prominent and more direct role in assisting industry and promoting national competitiveness. The role of academia in fostering technology transfer and economic growth is now considered an essential element of national S\&T policies (Baldini, 2006; Wang \& Guan, 2010). Knowledge and technologies from different fields will undoubtedly be combined to develop the products of the future. Few companies have access to the full range of knowledge available; most are compelled to obtain this knowledge from other companies or research institutes. One way to acquire the necessary knowledge is through collaborative work with other entities (Mahnken \& Moehrle, 2018).

INPI's 2019 ranking of resident applicants revealed that among the top twenty applicants, seventeen are HEIs (INPI, 2020). In contrast to other countries, innovations in Brazil are mainly emerging from universities. In a study performed in a national databank of university-industry relations survey conducted in 2008-2009 with leading Brazilian universities, Mikhailov, Puffal, and Santini (2020) pointed out that the most complex university-industry interactions - development-oriented and research-oriented - are the types of interactions that may lead a company to high innovativeness.
In 2016, the Brazilian legal mark of science, technology, and innovation was decreed to provide environments that gather infrastructure, institutional and cultural arrangements that may attract entrepreneurs, and financial resources. Universities, research centers, funding agencies, public enterprises, and mixed capital companies are now able to form strategic alliances to develop cooperation projects between enterprises, Scientific, Technological, and Innovation Institutions, and private entities as minority shareholders or through investment funds to establish products and new innovative processes, or, even more, by new public-private partnerships (Brazil, 2016).

In a knowledge-based economy, universities are demanded to play more active roles in fostering technology transfer and economic growth through the application and commercialization of academic research. The rise in academic patenting, for universities themselves, may encourage the faster commercialization and exploitation of university inventions from public research and development, generate both industrial funding and licensing income from patents, spur new startups and protect academic intellectual property (Mahnken \& Moehrle, 2018; Wang \& Guan, 2010). 


\section{Conclusions}

The functional food segment has emerged as a global trend that promises to stick around for years to developed economies and emergent nations. Recent advances in biotechnology, nanoscience, and preservation technology represent unique opportunities to innovate in the functional food industry. Successful product launches keep pace with the degree of innovation of companies and countries. This phenomenon is complex but measurable through patenting activity as an indicator of innovation.

This study delved into the functional foods segment through patenting activity, outlining the Brazilian scenario in recent years. The availability and ease of access to patent information, the periodic updating of databases by Intellectual Property Offices, and their relationship with inventive activity allow for close monitoring of technological trends, priority or target markets, and food industry pioneering players. The trends in the domestic market are straightforward - the population's awareness of the benefits of healthy food and the dietary habits that can tackle diseases such as lactose and gluten intolerance indicate that opportunities for improvement in the functional food sector exist.

Brazilian HEIs figure prominently in the patenting activity of functional foods. The role of universities goes beyond teaching and science and ventures into the generation of intellectual property. Universityindustry partnerships and research-oriented collaborative networks seem a feasible way to foster innovation in the food industry in Brazil. The evolving links among universities, funding agencies, and private companies are becoming a significant focus of Brazilian policymakers as the role of technology in social and economic development sets out in the country. From the data of the patent search, the study allowed us to infer that multinational companies tend to centralize only the production line in Brazil, keeping R\&D in their home country. It may reveal an opportunity to establish public policies that allow the incentive for alliances in the development of new products and technologies, whether through Universities or in the creation of other research centers, thus taking advantage of the potential of Brazilian researchers.

The limitations of this study format lie in linking inventions to products launched on the market and, most importantly, those that will be a sales success. Therefore, a structured patent search should be carried out continuously as a mean of monitoring the market and helping to forecast the technologies that companies are pursuing as innovations.

\section{References}

Abe, K. (2015). Functional food science in Japan: Present state and perspectives. Journal of Nutritional Science and Vitaminology, 61, S201. https://doi.org/10.3177/jnsv.61.S201

Alves, M. C. (2018). A SBPC e as fundações de amparo à pesquisa. Ciência e Cultura, 70(4), 8-10. https://doi.org/10.21800/231766602018000400003
Arai, S. (1996). Studies on functional foods in japan-state of the art. Bioscience, Biotechnology and Biochemistry, 60(1), 9-15. https:/doi. org/10.1271/bbb.60.9

Baldini, N. (2006). University Patenting and Licensing Activity: A Review of the Literature. Research Evaluation, 15(3), 197-207. https:// doi.org/10.3152/147154406781775878

Baldini, N. (2008). Negative effects of university patenting: Myths and grounded evidence. Scientometrics, 75(2), 289-311. https://doi. org/10.1007/s11192-007-1865-y

Bigliardi, B., \& Galati, F. (2013). Innovation trends in the food industry: The case of functional foods. Trends in Food Science and Techno$\log y, 31$ (2), 118-129. https://doi.org/10.1016/j.tifs.2013.03.006

Bigliardi, B., Ferraro, G., Filippelli, S., \& Galati, F. (2020). Innovation models in food industry: A review of the literature. Journal of Technology Management and Innovation, 15(3), 97-108. https://doi. org/10.4067/s0718-27242020000300097

Boland, M. (2008). Innovation in the food industry: Personalised nutrition and mass customisation. Innovation: Management, Policy and Practice, 10(1), 53-60. https://doi.org/10.5172/impp.453.10.1.53

Brazil Food Trends. (2020). São Paulo: Fiesp, Ital. Retrieved from http://www.brasilfoodtrends.com.br/

Brazil. (2016). Law no 13.243, of January 11, 2016. Dispõe sobre estímulos ao desenvolvimento científico, à pesquisa, à capacitação científica e tecnológica e à inovação. Brasília, DF.

Brazil. Brazilian Ministry of Health, National Health Surveillance Agency. Resolution of the Board of Directors - RDC n² 243, July 26, 2018. DOU, ed 144, s 1, p.100.

Chang, P. L., Wu, C. C., \& Leu, H. J. (2012). Investigation of technological trends in flexible display fabrication through patent analysis. Displays, 33(2), 68-73. https://doi.org/10.1016/j.displa.2012.03.003

Chesbrough, H. (2003). Open innovation: The new imperative for creating and profiting from technology. Boston: Harvard Business School Press.

Clarke, N. S. (2018). The basics of patent searching. World Patent Information, 54(S), S4-S10. https://doi.org/10.1016/j.wpi.2017.02.006

Clodoveo, M. L., Dipalmo, T., Rizzello, C. G., Corbo, F., \& Crupi, P. (2016). Emerging technology to develop novel red winemaking practices: An overview. In Innovative Food Science and Emerging Technologies (Vol. 38, pp. 41-56). Elsevier Ltd. https://doi.org/10.1016/j. ifset.2016.08.020

Coppens, P., Da Silva, M. F., \& Pettman, S. (2006). European regulations on nutraceuticals, dietary supplements and functional foods: A framework based on safety. Toxicology, 221(1), 59-74. https://doi. org/10.1016/j.tox.2005.12.022 
Cornell University, INSEAD, \& WIPO (2020). The Global Innovation Index 2020: Who Will Finance Innovation? Ithaca, Fontainebleau, and Geneva.

Federação das Indústrias do Estado do Ceará (FIEC) (2020). Índice FIEC de Inovação nos Estados. Retrived from https://arquivos.sfiec. org.br/nucleoeconomia/files/files/Indice\%20fiec\%20de\%20Inovacao/Indice-FIEC-Inovacao_2020_V10.pdf

Gaensly, F.; Brand, D.; Bonfim, T.M.B. (2012). Produção de levedura Sacchomyces cerevisiae ativa enriquecida com íons ferroso e férrico incorporados mediante adição aos meios de cultivo. BR 102012 0241692 A2. INPI. Instituto Nacional da Propriedade Industrial.

Garcez Júnior, S. S., \& Moreira, J. de J. da S. (2017). O backlog de patentes no Brasil: o direito à razoável duração do procedimento administrativo. Revista Direito GV, 13(1), 171-203. https://doi. org/10.1590/2317-6172201708

Hsieh, H. F., \& Shannon, S. E. (2005). Three approaches to qualitative content analysis. Qualitative Health Research, 15(9), 1277-1288. https://doi.org/10.1177/1049732305276687

Instituto Nacional da Propriedade Industrial (INPI). (2020). Ranking Top 50 INPI 2019 - Rankings dos depositantes residentes em 2019.

Instituto Nacional da Propriedade Industrial (INPI). (2021). Retrieved from https://www.gov.br/INPI/pt-br

Kim, G., \& Bae, J. (2016). A novel approach to forecast promising technology through patent analysis. Technological Forecasting and Social Change, 117, 228-237. https://doi.org/10.1016/j.techfore.2016.11.023

Kotilainen, L., Rajalahti, R., Ragasa, C., \& Pehu, E. (2006). Agriculture and rural development discussion paper 30 health enhancing foods opportunities for strengthening the sector in developing countries. Agriculture and Rural Development, 1-95. http://www.worldbank. org/rural

Mahnken, T. A., \& Moehrle, M. G. (2018). Multi-cross-industry innovation patents in the USA - A combination of PATSTAT and Orbis search. World Patent Information, 55(October), 52-60. https://doi. org/10.1016/j.wpi.2018.10.003

Makinen -Aakula, M. (2006). Trends in functional foods dairy market. In Proceedings of the third functional food net meeting.

Mascaraque, M. (2019). Top 5 trends shaping Health and Wellness. Euromonitor International Ltd. https://blog.euromonitor.com/top-5-trends-shaping-health-and-wellness/

Mikhailov, A., Puffal, D., \& Santini, M. (2020). University-industry relations and industrial innovation: Evidence from Brazil. Journal of Technology Management and Innovation, 15(3), 6-16. https://doi. org/10.4067/s0718-27242020000300006
Ministry of Development, Industry and Foreign Trade. (2020). INPI reduz estoque de pedidos de patente em 2019. Retrieved from https://www.gov.br/economia/pt-br/assuntos/noticias/2020/01/inpi-reduz-estoque-de-pedidos-de-patente-em-2019

Mitra-Kahn, B., Marco, A., Carley, M., D’Agostino, P., Evans, P., Frey, C., \& Sultan, N. (2013). Patent Backlogs, Inventories and Pendency: An International Framework. In IPO-\& USPTO joint report.

Nielsen Global. (2015). Nielsen's global health \& wellness survey: We are what we eat. Healthy eating trends around the world. Retrieved from https://content.money.com/wp-content/uploads/2015/05/nielsen_global_health_and_wellness_report_-_january_2015.pdf

OECD/Eurostat. (2018). Oslo Manual 2018: Guidelines for Collecting, Reporting and Using Data on Innovation, 4th Edition, The Measurement of Scientific, Technological and Innovation Activities, OECD Publishing, Paris/Eurostat, Luxembourg, https://doi. org/10.1787/24132764

Oliveira, I.S.; Carvalho, G.B.M.; Paulo, E.M.; Oliveira, A.P.A. (2016). Produção de cerveja ácida funcional com adjunto de uva e bactérias láticas. BR 1020160044170 A2. INPI. Instituto Nacional da Propriedade Industrial.

Pagani, A.A.C.; Morais, A.B.L.; Xavier, A.C.R. (2014). Bebidas fortificadas com microcápsulas de polpa de frutas. BR 1020140246282 A2. INPI. Instituto Nacional da Propriedade Industrial.

Rai, A. K., Pandey, A., \& Sahoo, D. (2019). Biotechnological potential of yeasts in functional food industry. In Trends in Food Science and Technology (Vol. 83, pp. 129-137). Elsevier Ltd. https://doi.org/10.1016/j.tifs.2018.11.016

Schumpeter, J. A. (1988). ). A teoria do desenvolvimento econômico. São Paulo: Nova Cultural.

Sharma, P., \& Tripathi, R. C. (2017). Patent citation: A technique for measuring the knowledge flow of information and innovation. World Patent Information, 51, 31-42. https://doi.org/10.1016/j. wpi.2017.11.002

Spence, J. T. (2006). Challenges related to the composition of functional foods. Journal of Food Composition and Analysis, 19(SUPPL.), 2005-2007. https://doi.org/10.1016/j.jfca.2005.11.007

Szymańska, E. (2017). User-Driven Innovation - The Concept and Research Results. Procedia Engineering, 182, 694-700. https://doi. org/10.1016/j.proeng.2017.03.182

Vanholme, B., Desmet, T., Ronsse, F., Rabaey, K., Van Breusegem, F., De Mey, M., Soetaert, W., \& Boerjan, W. (2013). Towards a carbonnegative sustainable bio-based economy. In Frontiers in Plant Science (Vol. 4, Issue JUN, p. 174). Frontiers Research Foundation. https:// doi.org/10.3389/fpls.2013.00174 
Wang, G., \& Guan, J. (2010). The role of patenting activity for scientific research: A study of academic inventors from China's nanotechnology. Journal of Informetrics, 4(3), 338-350. https://doi.org/10.1016/j. joi.2010.02.002

World Intelectual Property Organization (WIPO) (2020a). World Intellectual Property Indicators 2020. Geneva: World Intellectual Property Organization.
World Intelectual Property Organization (WIPO) (2020b). What's Intellectual Property. Retrieved from https://www.wipo.int/edocs/ pubdocs/en/wipo_pub_450_2020.pdf

Zegler, J., Moore, S., Beckett, A., Haydon, R. M., \& Faulkner., D. (2019). Global Food and Drink Trends 2030. Mintel'S 2030, 24. Retrieved from https://downloads.mintel.com/private/vKd7N/files/817369/ 